\title{
Moral Realism and the Policy Preference of China and the US Towards the South China Sea
}

\author{
Fengjia Lei ${ }^{1}$ \\ ${ }^{1}$ Shanghai University of Political Science and Law, Shanghai, China \\ Correspondence: Fengjia Lei, Shanghai University of Political Science and Law, No.7989 Wai Qing Song Road, \\ Qingpu District, Shanghai 201701, China. E-mail: lexielay09@gmail.com
}

Received: January 6, 2022

Accepted: February 8, 2022

Online Published: February 27, 2022

doi:10.20849/ajsss.v7i2.1005

URL: https://doi.org/10.20849/ajsss.v7i2.1005

\begin{abstract}
Moral realism is an important theory in the Chinese School of International relations theory, it argues that the political leadership of each state has a decisive influence on policy preferences. This paper used the moral realism model to explain the policy preference of China and America in the South China Sea. It found that it can explain the restraint and confrontation of both sides, but failed to justify the tension between China and its neighboring countries.
\end{abstract}

Keywords: moral realism, South China Sea, policy preference, political leadership

\section{Introduction}

From the early 1990s, a large scale of western theories like realism and behaviorism were introduced to Chinese scholars. Among them, the works of realism were being translated the most, which brought a huge influence on Chinese international politics view (Men, 2016). After entering the 21st century, Chinese scholars noticed that the mainstream IR theoretical analysis, description, interpretation, and prediction mainly focus on the Western-centered international order (Pan \& Chen, 2019), so they have increased their criticism and application of western theories, meanwhile started to explore traditional Chinese culture, conclude the principles neighborhood diplomacy of ancient Chinese into the theoretical framework of international relations, trying to establish IR theory with "Chinese characteristics" (Guo, 2017). The development of moral realism started from this period. Realism argues that in a period of power transition, there is a danger that the rising power will resort to war or force (Kristensen \& Nielsen, 2013). However, this theory has a hard time explaining the peaceful rise of China. Therefore, Professor Yan Xuetong draws extensively from the Chinese pre-Qin classics (Trigkas, 2020), introduce the element of moral into the framework of realism, use a western paradigm, and put the philosophy of ancient Chinese thinkers into it (Kristensen \& Nielsen, 2013), try to provide an explanation to power transition in the current world, in other words, how does a rising power replace the current world-leading power (Yan, 2016).

Yan himself strongly advocates the scientific method, and he believes that "all the science should be like natural science, that is universal" (Yan, 2019). Therefore, he constructed moral realism through the path of natural science positivism, using the independent variables extracted from the pre-Qin thought to explain the dependent variables in international relations, such as national foreign strategy. But moral realism also received many critics, the offensive realist John Mearsheimer argued that "For a true realist, the thing to avoid is, in fact, a sense of morality" (Mearsheimer, 2013). Guo (2017) argued that if the dominant and rising power are both aiming for system dominance and follow the same way to obtain international leadership, then it is not necessary to introduce the pre-Qin thought, because the framework of realism is sufficient to explain the problem. But if it wanted to emphasize the contribution of traditional Chinese thought, then the assumption that each state has the same acting logic does not fit anymore. Buzan (2014) mentioned that compares to the English school, Chinese IR theory has a strong national catachrestic. Kim (2016) and Demir (2017) both raised the question that is the theory study in China, especially moral realism, serves the interests of Chinese politics and CPC? This question is remaining unanswered.

It has been nearly a decade since the advent of moral realism, but scholars seldom put the theory into practice. Only Yan himself used this theory to explain the ancient Chinese event and seek for the rationality of Chinese foreign policy Striving for Achievement (Yan, 2014). But when it comes to contemporary international phenomenon, whether it can provide favorable persuasion? Will the outcome of the policy preference fit the assumption of moral 
realism? This paper is aiming to use moral realism to explain the policy preference of China and America in the South China Sea from 2009 to 2020, in order to test if the outcome fits the hypothesis of moral realism. This paper is divided into three sections: The first part is to introduce the theoretical framework of moral realism, the second section is to define the leadership type of each leading body, the third part is the hypothesis of under moral realism and the discourse analysis of Chinese policy preferences toward the South China Sea and the examination of moral realism. Lastly, the conclusion will be raised.

\section{The Theoretical Framework of Moral Realism}

Moral realism is a theory of international relations that emphasizes that political leadership determines the change of the balance of power between great powers and the change of the international system. The core issue of this theory is how the rising state replaces the current dominant power, that is to explain the shift of the world center. Political leadership serves as the core independent variable in the theory, and it is the key to changing the international configuration, orders, norms, and even system (Yan, 2019). Moral realism is based on the assumption of realism that the international community is an anarchic system in which all states pursue their specific strategic interests on the basis of self-help (Morgenthau, 1948). When a country reached the level of rising or dominant power, morality will have a great influence on the effect of national strategy, especially the effect of establishing international norms (Yan, 2019). While morality here refers to the governmental morals which differ from the personal and international one. Personal morality is related to the lifestyle, loyalty to the spouse can be considered personal moral for instance. The content of international morality would change with time, but some universal international morality will remain the same under any historical conditions, for example, observing the covenant or paying the debt. By contrast, governmental morality has two levels of meaning: Internally, it means to be responsible for the interests of the people, from an international politics perspective, this refers to improving the international status of the country (Yan, 2019); Externally, governmental morality is to maintain the strategic credibility of the country.

In accordance with the sense of governmental morality, leadership can be categorized based on two variables: attitude towards status quo of the leader and its responsible actions regarding policy mistakes (Yan, 2019). Moral realism divided leadership into four types: inactive, conservative, proactive, and aggressive. Inactive and conservative leaders have no tension to change the status quo, while proactive and aggressive leadership have a strong desire to improve the international status of their country and expand the international power. Conservative and proactive leadership will take credibility into account, so they are responsible for the outcome of their policy. On the contrary, inactive and aggressive leadership are irresponsible and perceive with their policy even though it undermines the national credibility and capacity.

As the type of leadership at the state level is determined by its sense of governmental morality, different types of leadership will result in differential growths of national capability (Yan, 2019). Moral realism considers the comprehensive strength as the dependent variable of pollical power, and according to different comprehensive strengths, countries can be divided into dominant state, rising state, regional state, and small state. The choice of a country's foreign strategy is determined by its objective national interest and the method of realizing them, national interests and method are determined respectively by the country's comprehensive strength and the leadership type. Therefore, the strategic preference of a country is decided by the combination of comprehensive strength and leadership type.

\section{Political Leadership Type of Chinese and the US Presidents}

From the argument of the last section, we can indicate that moral realism first determines the strategic interests of a country based on its position and comprehensive strength, and then analyzes the political leadership type, those two factors influence the strategic preference of a state together. Political strength is could affect the comprehensive strength, and the previous one is related to the government-run by political leaders. Therefore, political leadership has become the key independent variable of moral realism, identifying the political leadership type is quite essential to scrutinize the strategic preference. In the international competition, the result depends on the strategies of both the dominant state and the rising state instead of the decision just of one side. Hence, the leadership types of both sides are needed to be distinguished.

Decision-making is a collective action rather than the individual leaders' thought, so political leadership in moral realism refers to the leading group of policymakers, not just a single supreme leader (Yan, 2019). In this paper, for the convenience of understanding, the name of the leader is used to indicate the leadership body he or she is in. When the political leadership is not just about the supreme leader, it is legit to say that we should not categorize it based on the personality or the ideology of him or her, but look at the leading body's sense of national responsibility and capacity to carry out its duty (Yan, 2019). From 2009 to 2020, Barack Obama (2009 - 2017) and 
Donald J. Trump (2017 - 2020) entered the White House in succession, China also experienced two presidents Hu Jintao (2003 - 2013) and Xi Jinping (2013 - Present). Those four leaders are obviously various from each other, as we can see from their attitude towards the status quo and the responsibility of the likely outcome of their policies (Yan, 2019).

\subsection{Barack Obama}

Obama was the president of the US from 2009 to 2016. During his presidency, the main goal was to practice "smart power" diplomacy (Guerlain, 2014). The US implemented a global retrenchment strategy as a whole, but partly shifted its focus to the Asia-Pacific region. Besides, the strategy of counterterrorism was adjusted as America must get away from the quagmire of the wars in Iraq and Afghanistan. Obama defined himself as a pragmatist (Obama, 2010). Hence, he placed less emphasis on promoting democracy abroad and more on assuring national security interests with pragmatic realism methods. As a result, he was very cautious about the use of force in foreign policy (Nau, 2013).

Obama entered the White House facing the worst recession caused by the financial crisis after World War II, also two wars inherited from the Bush administration which brought a high cost of life and economic burden, these situations were calling for him to make a change from his predecessor, whilst due to the pragmatism thought, Obama tended to attentive to political reality. Despite Obama had repeatedly mentioned that America has not declined, he was still conscious of the limits of the power of America cannot support it to be the "world police" as the Bush pursued (Tao, 2016), just like what he said on the Military Academy Commencement Ceremony "Just because we have the best hammer, doesn't mean every problem is a nail." (Obama, 2014), it can be seen in his Asia-Pacific Rebalance strategy. This strategy is more rule-oriented with a goal of formulating rules for regional security hotspot issues, promoting countries in the Asia-Pacific region to "abide by the rules" (Zhu, 2018). Obama, at least through what he claimed, tended to take no side when it came to sovereignty disputes of the South China Sea, he also opposed the use of force and coercion. Compares to Bush, Obama has less ambitious to attain international power, like he reiterated lot, "Leadership comes at a price" (Obama, 2010). Besides, Obama values his credibility and is willing to take responsibility for his policies. The Asia-Pacific rebalance strategy coincided with a steady decline in US defense spending, this caused a widespread belief among U.S. Allies in this region that cuts in defense spending will affect America's investment in the Asia-Pacific area (Zhou, 2019). Obama stressed in a speech during a visit to Australia in 2011 that "Let me say it again: reducing America's defense spending will not affect our investments in the Asia-Pacific." (Obama, 2011), his emphasis on the credibility of his commitments has two effects: while strengthening the confidence of allies, it may also encourage them to do more on security, thus spreading the costs of action in the Asia-Pacific region. Meanwhile, Obama had also scaled back his military commitments in the area. When disputes arose, he was more willing to give diplomatic support, avoided direct military intervention, and be reluctant to make explicit commitments on military obligations in disputed areas. We can see Obama was aiming for developing "a new, multilateral global order with America still in the lead ... but sharing more responsibilities and more burdens with others where possible or necessary" (Indyk, Lieberthal, \& O'Hanlon, 2012) in his term. Although he was still trying to maintain the hegemony of America in the international society, he had no ambition to attain international power any greater than what their predecessors achieved (Yan, 2019). Also, he attached importance to the credibility and responsibility of his policies, take all these factors into consideration, Obama can be defined as a conservative leader.

\subsection{Donald Trump}

The succession of Obama, Donald Trump, is a completely different type. Trump had never held public office before winning the presidential election, he entered the political arena with a background in New York real estate and reality television shows, so he has "demonstrated a remarkable ability to navigate modern media, challenge conventional wisdom and create disruptive innovations" (Nye, 2019). Trump's business experience and anti-establishment tendencies had influenced his logic of decision-making to varying degrees, also making him dispose to a zero-sum mentality when it comes to policymaking (Diao, 2019). His utilitarianism thought is significantly different from liberal internationalism, the mainstream trend of thought in American diplomacy after the cold war. Trump stressed cost-benefit accounting, which means minimizing the input in international affairs so that it can reduce the burden on the US. As a canny businessman, Trump emphasized low costs and high yields. As a result, he reduced the State Department's diplomatic budget and international aid, but it increased the defense budget and strengthen America's defense forces (Wang J., 2017).

Since the early days of his campaign in 2016, Trump had already spelled out his goals in two words: America First. This slogan somewhat reflected his new isolationist streak, the isolation was embodied in an impulse to abdicate international responsibilities, a representative phenomenon is to withdraw from a range of international 
organizations and arrangements, totally disregarding the commitment and responsibility of the US government. Other than abandoning multilateralism, Trump's leadership return to great-power competition, mainly with China. From December 2017 to February 2018, the Trump government issued four documents, stating that "the United States will face to its growing world political, economic, and military competition to respond" (The White House, 2017). Moreover, in Trump's eyes, the central challenge to US prosperity and security is a shift from terrorism to the re-emergence of long-term strategic competition among states, with China as its main strategic competitor (The White House, 2017). In the South China Sea issue, Trump abandoned Obama's neutral stance and stepped up diplomatic, military intervention in the region. His Indo-Pacific Commander Philip Davidson highlighted the military threat of China in the South China Sea, calming that China has the ability to control this region one day, armed conflict was the only way to stop it (Daidson, 2019). Patrick Shanahan, the then Secretary of Defense, accused China of making "excessive claims" in the South China Sea and restarted implementing Freedom of Navigation Operations (FONOP) in the South China Sea, which have been suspended for three years (Heydarian, 2020). Trump upgraded US's diplomatic involvement to military involvement in the South China Sea issue, increasing American military presence in the area. In contrast to Obama, Trump has become increasingly militarily belligerent and threatening.

We can see the belief in social Darwinism in Trump, he has a strong desire to increase the power of America by engaging in a series of risky behaviors. Trump's ambition to regain power and his irresponsible attitude towards the potential outcome of his policy demonstrates that he is an aggressive leader, which undermined American democracy and international credibility as widely agreed (Mettler, 2017).

\subsection{Hu Jintao}

Compares to the US president, the Chinese leadership is easier to distinguish their type. Since the reform and opening to the outside world, the type of Chinese leaders has shown a certain continuity. From 1979 to 2002, China has never been involved in any war or major military conflict, and its relations with its neighbors had risen, some historical inherited issues had been solved during that period. relations with major powers remained stable as a whole (Zhang Q., 2014). Hu Jintao took office under the condition of a peaceful and stable external environment. Thus, he showed a strong willingness to maintain the international status quo and the achievement of his predecessors, as he stated "The world today is undergoing major changes and adjustments, but Peace and development remain the theme of the times. In order to pursue peace, cooperation has become an irresistible trend." Contemporary China's relations with the rest of the world have undergone historic changes, China's future and destiny are increasingly linked to those of the rest of the world." (Hu, 2007).

$\mathrm{Hu}$ himself, like his predecessors Deng Xiaoping and Jiang Zemin, is an economic determinist. During his presidency, he promoted the method Scientific Outlook on Development with a core concept of focus on economic development, seizing opportunities to accelerate economic development and maintain the momentum of steady and relatively fast economic development. For $\mathrm{Hu}$, economic development is the optimal choice to maintain the status quo. Through its own development, China could continually contribute to the common prosperity of the region, and eventually the world at large (Jin \& Jin, 2018). Many speeches made by Hu contain words like "economic development" common development" peaceful development", which demonstrate that he is not pursuing greater power. On the other hand, he laid more emphasis on international cooperation, just like the concept "Harmonious world" he promoted in Asia-Africa Summit in 2005, "We propose that people of all countries should join hands to build a harmonious world of lasting peace and common prosperity" (Hu, 2005). We can see from Hu that he clearly inherited the idea of keeping a low profile, viewed the economy as the key factor to determine the comprehensive national strength, this makes his leadership a conservative one.

\subsection{Xi Jinping}

In contrast to his predecessors, $\mathrm{Xi}$ Jinping has abandoned the humble approach to diplomacy. It was clear at the beginning when Xi took office that he does not want to be as obscure as his predecessors had been for decades. His goal is clear, which is to make the once-mighty empire return to its former place in the international community (Deng Y., 2020). Unlike Hu Jintao who focuses on economic development, Xi lays more emphasis on political strength, this might have something to do with his early grassroots experience. The concept of the "Chinese Dream" reflects his understanding and ambition about political strength. Xi defined the Chinese Dream that "Realizing the great rejuvenation of the Chinese nation has been the greatest dream of the Chinese people since modern times..." (Xi, 2013). He constantly stressed the term "national rejuvenation", which plainly indicates his ambition of improving China's international status and increasing Chinese international power. Xi made it clear at the 19th CPC National Congress that "...now China, in the new era, will be strong, not only at the national level but also on the international stage." (Xi, 2017). He is not satisfied with the status quos any longer, and this idea of him makes 
him tend to give up Deng's legacy Keeping a Low Profile, and turn more to Striving for Achievements (Yan, 2014).

$\mathrm{Xi}$ has taken a more proactive stance than his predecessors, he holds the idea that diplomacy is an inevitable requirement for realizing the Chinese dream of national rejuvenation. Therefore, under his presidency, we can witness a more active assertive diplomacy style than before. Sometimes his stance is referred to as "Wolf Warrior Diplomacy", which is aggressive diplomacy mean (Zhang J., 2020). Xi initiated a new foreign policy known as the "Major Country Diplomacy", which is aspiring to exercise China's leadership in its peripheral regions and the international arena commensurate with China's status as a major power (Lida, 2020). This shows that Xi has accepted China's status as a great power, also ready to promote China's international image as a responsible major power, just as what he said: "We should promote reform of the international system and global governance, so that...China will have greater representation and bigger say." (Xi, 2018). As for the South China Sea issue, Xi did not try to avoid discussing it on multilateral occasions as in the past. Instead, he loudly declared that China would resolutely safeguard its territorial sovereignty, maritime rights, and interests (Xi, 2016). When Xi presided over a group study session of the Political Bureau of the CPC Central Committee, he made it clear that "We should be prepared to deal with all kinds of complex situations, improve our ability to safeguard maritime rights and interests (Xi, 2016)." China's military training and regular patrols in the South China Sea have all been significantly enhanced under Xi's presidency, as well as the management of the South China sea-built artificial islands in the Nansha Islands and set up Sansha for instance.

Nevertheless, $\mathrm{Xi}$ is not aiming for pushing military settlement of the South China Sea issue. During his meeting with Obama, he said that China is striving to peacefully resolve disputes through direct consultation and negotiation with countries concerned $(\mathrm{Xi}, 2017)$. Xi claimed that China abides by the provisions of the United Nations Convention on the Law of the Sea (UNCLOS) and the Declaration on the Conduct of Parties in the South China Sea (DOC), upholds the legal regime of the sea on the basis of international law. All relevant disputes should be resolved peacefully by the parties concerned through friendly negotiations and consultations, internationalization and external interference should be opposed.

Henry Kissinger (2014) commented in his book World Order that Xi "has sought to turn China into a shaper of the international order, transforming it from a follower to an innovator.". From the arguments above, we can conclude that $\mathrm{Xi}$ has a strong desire of changing the international status quo and enhancing Chinese international power, but initially via political and diplomatic means. so $\mathrm{Xi}$ can be perfectly categorized as a progressive leader.

In sum, Obama is a conservative leader who prefers to control hegemony costs while maintaining America's international status as a dominant power. The leadership type of Trump is quite aggressive that he would use all means including the military to gain power for the US. Hu Jintao is a conservative leader with the characteristic of economic determinist, he views economic interest as the supreme one and wants to maintain the achievement of his predecessors. Xi Jinping, in contrast, has a strong desire to improve China's international status in a political way, but he is unafraid of confronting other countries, which makes him a proactive leader.

\section{Chinese and American Policy Preference Towards the South China Sea}

\subsection{The Hypothesis of Moral Realism}

Moral realism divided the dominant power as a humane authority, hegemony, and tyranny, different great power would adopt different strategies to gain more power, and the strategic preference of each state is determined by the combination of comprehensive strength and leadership type of that country. As it argued before, the US has been the dominant state from 2009 to 2020, whilst China was the regional state of Asia, after becoming the second-largest economy in 2010, the national comprehensive strength and international influence of China have reached the level of a rising state in the global arena. Accordingly, the strategic interest of the US should always be maintaining the system domination, in other words, keeping its position as the only superpower in the world. Meanwhile, China should seek for being a great power regionally in Asia before 2010 as it was only a regional state. With the improvement of its comprehensive national strength, the strategic interest of China should to pursuing the system domination as its strength gap with the dominant state is becoming more and more narrow. Because the dominant state and the rising state are both in pursuit of the world-leading power, and moral realism assumes that the nature of power is zero-sum, one country's gain would unavoidably cause a loss to the other side, the power redistribution will lead to a structural conflict between the two countries (Yan \& Yang, 2013).

Strategic interest cannot define the strategic preference of a country alone, the political leadership type of each state should also be taken into consideration. The last section defined the leadership type of presidents of the US and China. Obama is a conservative leader that would like to maintain the status quo and conserve the power of America. He values the credibility of America, so when coming to policymaking, moral is an important factor he 
would respect. Obama's Chinese counterpart Hu Jintao shares the same leadership type with him. As a typical conservative leader, $\mathrm{Hu}$ regards economic interest as the supreme when there is no military invasion. Hence, Hu would take economic cooperation approach to reduce external pressure for the purpose of retaining the existing power of China. Whilst Trump, who is defined as the aggressive leadership type, would take a more risky approach in order to maximize the power America could gain, regardless of the international reputation. All his strategies are in service of "make America great again", so acute foreign policy should not be unusual for him. Xi Jinping, who has a proactive leadership style, is striving for improving China's international status. For him, we should observe the tendency of appropriate reforms. Rather than this, he should also seek political support and cooperation with the neighboring country in the interest of changing the status quo and competing with the current dominant state.

The combination of comprehensive strength and political leadership type determine the strategic preference of each nation. The result of this strategic competition is dependent on the respective strategies of both sides, rather than on the decision of just one side. According to the assumption of moral realism, for the case of America during Obama's presidency, a dominant state with a conservative leader should lead to an external strategic preference of controlling the hegemony cost, reducing military spending overseas to boost the domestic economy. After Trump took office, with a strong desire of increasing the power of the US, America's strategic preference was altered by using all means to contain the rising state to avoid power redistribution, including the military one. On the Chinese side, before 2010, with a conservative leader in a regional state, the strategic preference back then should be to strengthen regional economic cooperation and avoid conflicts with neighboring countries. After becoming a rising power after 2010, under Hu's lead, China's strategic preference should still be expanding global economic cooperation temporarily relieve the tension between the dominant state by this approach. Meanwhile, with a proactive leader $\mathrm{Xi}$, China as a rising power should have a preference of building good-neighborly relationships and partnerships and making allies with the neighboring countries to break the containment of the dominant country and gain more international support.

Now let us put the strategic preference of each country in each period into the case of the South China Sea. In recent years, the South China Sea issue has gradually become one of the most important topics in China-US relations. The two sides have delivered their own attitude about the South China Sea diplomatically, and there have also been tensions and even frictions on the military front. The rivalry between China and the United States is unfolding through the South China Sea issue, with each beginning to assess the other's intentions on a strategic level (Fu \& Wu, 2016). Based on the strategic preference, we could infer the Chinese and American theoretical foreign policy towards the South China Sea. To the US side, the preference of Obama's presidency is to control the hegemony cost and military retrenchment, thereby, theoretically speaking, America is legit to keep an eye on the South China Sea as it still has the preference of maintaining its international influence, but unlikely to provide military support to its alliance in this area. When entering Trump's era, which started in 2017, the strategic preference of Americans is to gain global power and contain the rise of the rising state draw on all available. In this case, we should observe the trend that Americans should pay more attention to the direction of the South China Sea issue and involved in the situation deeper, and it would not be stingy with their own military support, even may take the initiative to launch a military offensive to China in the South China Sea. On the Chinese side, before 2010, its strategic preference to the South China Sea should highlight the economic cooperation and try to avoid dispute in this area as much as possible. From 2010 to the end of Hu's term, which is 2013, China should deepen the economic cooperation with neighboring countries in order to promote political relations and seek to release the tension between America, so the policy of China towards the South China Sea in this period should be restraint. After Xi took over the presidency, Chinese strategic preference is enlarging the international support, which means we could see the cooperation in the so-called high politics range with the South China Sea peripheral countries to improve its international power and to obtain the political and military support necessary to counter the dominant state's suppression.

In sum, in the period of 2009 to 2013, America reduced its military cost in the South China Sea and China was seeking economic cooperation in this region, so the foreign policy of both sides should be restraint towards the South China sea. From 2014 to 2017, the preference of America stayed the same but China was pursuing high political cooperation with neighboring countries, which mainly are allies of the US, this would inevitably intensify the structural conflicts between the two sides. In this period, the condition we should observe is that confrontation in the South China Sea has intensified, but only at the political level. After 2017, America gave up on restraining its action in the South China Sea, so the confrontation should be upgraded to the military level between China and the US. Accordingly, Chinese policy preference towards the South China Sea should be seeking for economic cooperation and practice restraint from 2009 to 2013, later pursuing political support and start to confront the dominant power in this region from 2014 to 2017, finally take a tougher attitude to the sovereignty claim and face 
the confrontation head-on, the use of force is not ruled out.

\subsection{The Situation in the South China Sea}

In order to understand the situation in the South China Sea, this paper takes the regular press conference of the Ministry of Foreign Affairs of China as the analysis object. Questions raised by journalists at the press conference reflect the public's interest in China's diplomacy, the Spokesperson's answers are formal and could be seen as authoritative explanations of the Chinese government's positions and views on relevant issues (Zhang \& Yang, 2017). Spokesmen's statements on major or sensitive events and their answers to reporters' questions have become a bellwether of China's policy. The Ministry of Foreign Affairs of China would publish the transcript of each press on their official website, so this paper takes the transcript of the regular conference from 2009 to 2020 as a sample, try to distinguish the foreign policy towards the South China Sea.

Questions related to the South China Sea were raised 184 times in the regular press conference. As shown in figure 1, from 2009 to 2013, South China Sea-related issues were only brought up 20 times in total. This phenomenon fits the corollary made before that during this period, both sides had exercised restraint in their foreign policy on the South China Sea, so the situation in the South China Sea is occasionally frictional but generally stable, the dispute in this area was not a regional hotspot issue. Seems 2014, questions related to the South China Sea have been brought up more and more frequently, 2018 reached the top of 46 times. It can be interpreted as the situation of the South China Sea has become a common concern, and the atmosphere was getting gradually testified. Broadly speaking, from 2014 to 2020, tensions in the South China Sea are rising, it is consistent with the hypothesis of moral realism that confrontations should emerge in this area. From graph 1 we can indicate that the overall trend of the situation in the South China Sea coincides with the hypothesis that it remained stable from 2009 to 2014, after 2014 the confrontation escalated.

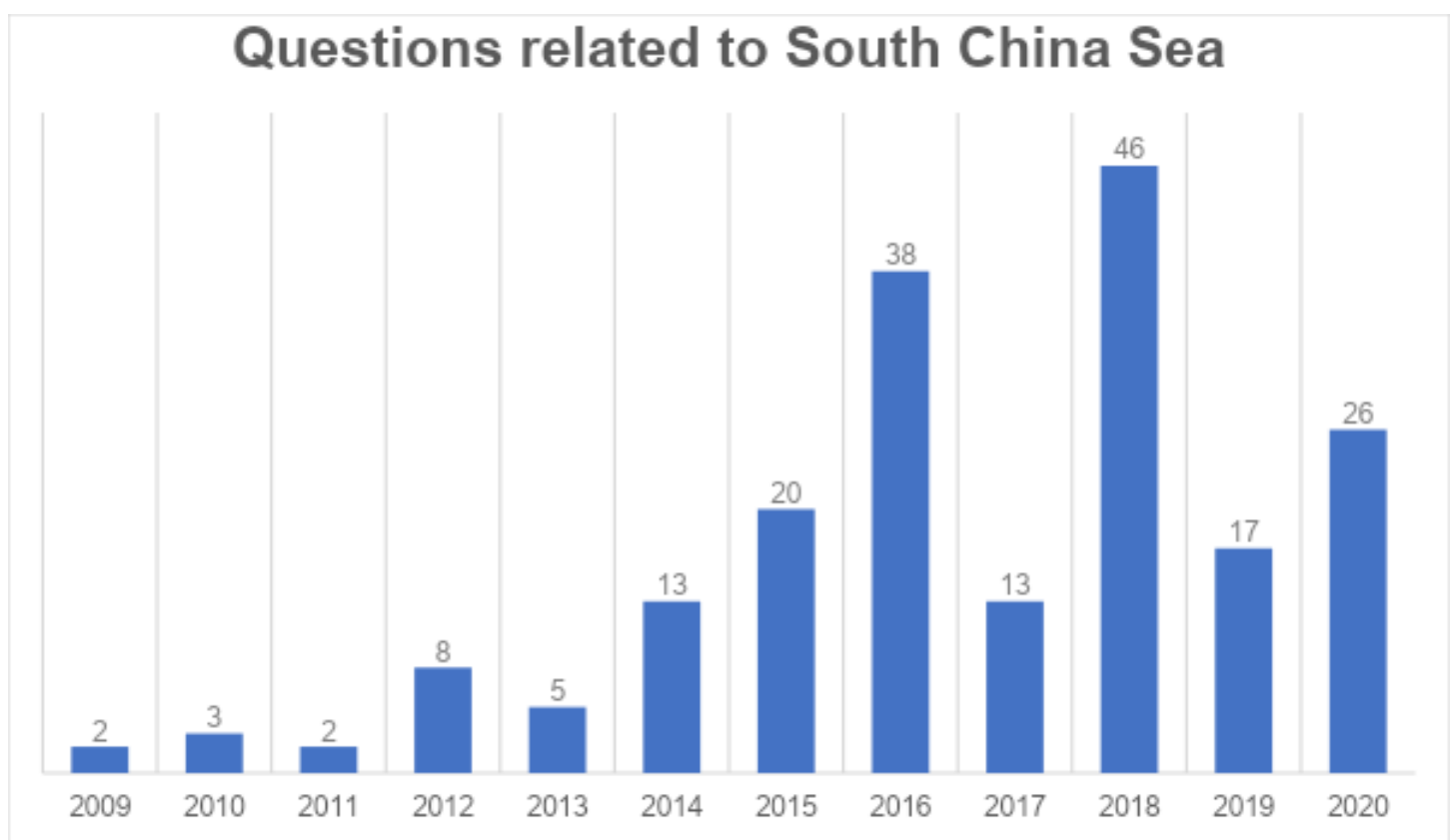

Figure 1. Number of questions related to the South China Sea raised at the regular press conference of Ministry of Foreign Affairs of China

Source: Official website of Ministry of Foreign Affairs of the People's Republic of China, https://www.fmprc.gov.cn/web/

According to the hypothesis and graph 1, we could assemble the year 2009 to 2013 as a group since those years constitutes a so-called controllable period. Similarly, 2014 to 2016 can also be grouped up as issues in the South China Sea are on a rapid rise. Finally, from 2017 to 2020 can be viewed as a period that the South China Sea is a continuous hotspot issue. 
2009 - 2013

In this period, issues about the South China Sea were raised 20 times. Among all the questions being asked, only two were about American, which was "Did the South China Sea issue come up during the fifth round of China-US Strategic and Economic Dialogue?" and "The US Senate passed a resolution 'reaffirming the strong US support for the peaceful resolution of territorial, sovereignty and judicial disputes in the Asia-Pacific ' to put pressure on China over the South and East China Seas. What is China's comment?". The answers to those two questions are relatively short with no more than three sentences, and the expression the spokesperson used was quite moderate, like "We reiterate that" "We hope that". It can be indicated from the reply that at this time, China did not want to take a hard line on America when facing the issue of the South China Sea as moral realism suggest.

Except for the two questions about America, the other 18 questions are all related to Vietnam and the Philippines, mostly about the dispute on maritime navigation and oil exploration, no military operation was involved. Regarding the answer, as graph 2 shows, 53\% of them are neutral. For example, when being asked for views about the China-Philippines arbitration tribunal on the South China Sea disputes, China gave this reply: Bearing in mind the overall interests of maintaining bilateral relations and peace in the South China Sea, China has always been committed to resolving relevant disputes through bilateral negotiations and consultations with the Philippines. Resolving disputes over territory and maritime rights and interests by sovereign states directly concerned is also a commitment made by the signatories of the Declaration on the Conduct of Parties in the South China Sea (DOC). The DOC should be fully and earnestly implemented. China is committed to resolving territorial and maritime delimitation disputes through bilateral negotiations in accordance with relevant provisions of international law and the idea of the DOC (Ministry of Foreign Affairs of PRC, 2012). China did not express its opposition explicitly, instead, it took an ambiguous stance about the South China Sea issue. Besides the neutral answer, $11 \%$ of the replies show a positive attitude towards the dispute. They mainly demonstrate the idea of "promoting joint development while shelving differences" (Deng X., 1983). During this period, China's policy on the South China Sea is to maintain the status quo, avoid escalating the South China Sea issue into the next grade. Meanwhile, China also shows a preference for cooperation in this area, just as the prediction of moral realism.

\section{China's attitude towards questions of South China Sea from 2009 to 2013}

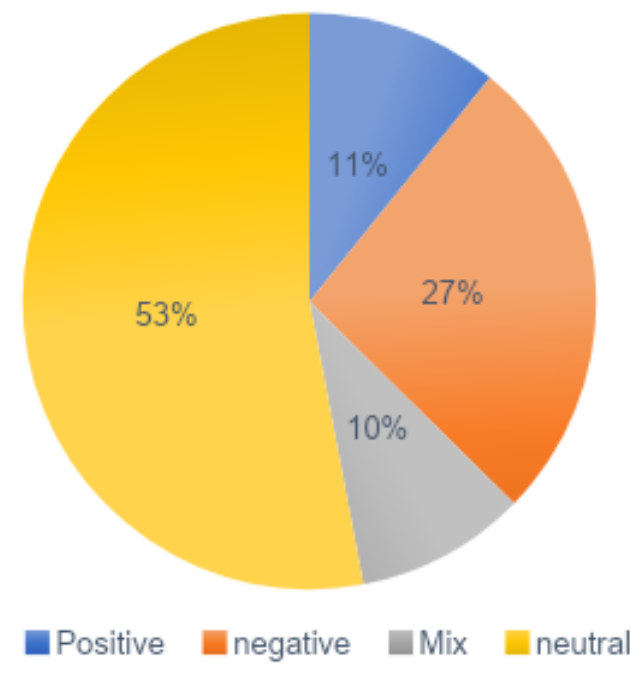

Figure 2. China's attitude towards questions of South China Sea from 2009 to 2013

Source: Official website of Ministry of Foreign Affairs of the People's Republic of China, https://www.fmprc.gov.cn/web/

2014 - 2016

The supreme leader of China was changed into someone who is another type in 2013, the strategic preference of 
Chinese policy was also altered correspondingly. From 2014 to 2016, 71 questions about the South China Sea were raised, which shows the unfortunate fact that this issue has already upgraded to a hot spot. Notably, 30 of the questions were about America, this could act as evidence to show that friction between China and the US over the South China Sea has intensified. In 2014, the United States made clearer statements on China's neighborhood issues, showing direct involvement in the dispute and favoring its Allies and other dissidents in the South China Sea issue. On February $5^{\text {th }}$ this year, Daniel Russel, the US assistant secretary of state for Asia Pacific affairs, accused the Chinese claim of "dotted line" in the South China Sea "lacks the basis of international law" and "affects peace and stability in the region" (Russel, 2014). This is the first time US officials have challenged China by name over the South China Sea dispute. The Chinese response to this is "China's maritime rights and interests in the South China Sea have been formed by history and are protected by international law. With regard to maritime disputes with relevant countries, China has been committed to resolving them through negotiation and consultation with countries directly concerned. We urge the US side to take a rational and fair attitude, contribute to regional peace, stability, prosperity, and development, instead of ruin it." (Ministry of Foreign Affairs of PRC, 2014). Compares to the previous period, rather than being conservative, the expression states Chinese intention clearly. It shows that the Chinese attitude towards South China Sea issues is more and more active. As a rising state, China is gaining bigger power, therefore, it would take the initiative to reinforce its strength in the South China Sea. While America as the existing dominant power will suppress the action of China because its preference is to avoid the power redistribution. As a result, the confrontation between those two sides took place.

Moral realism works well in predicting the confrontation between China and America, but according to its logic, China as a rising power should enlarge its international support, especially the political and military support in order to compete with the existing dominant state, and the starting point would always be the neighboring countries. Therefore, China should take the good-neighborly policy and minimize friction with neighboring countries. Nevertheless, 25 of the question raised in this period were Philippine related, 9 about Vietnam, and 3 were Malaysia affiliated. Figure 3 shows the words which appeared most frequently in the answer. Expect the names, we could see words like "declaration" "disputes" issue" "arbitration". Apparently, the relations between China and its neighboring countries have not eased, frictions have even become more serious.

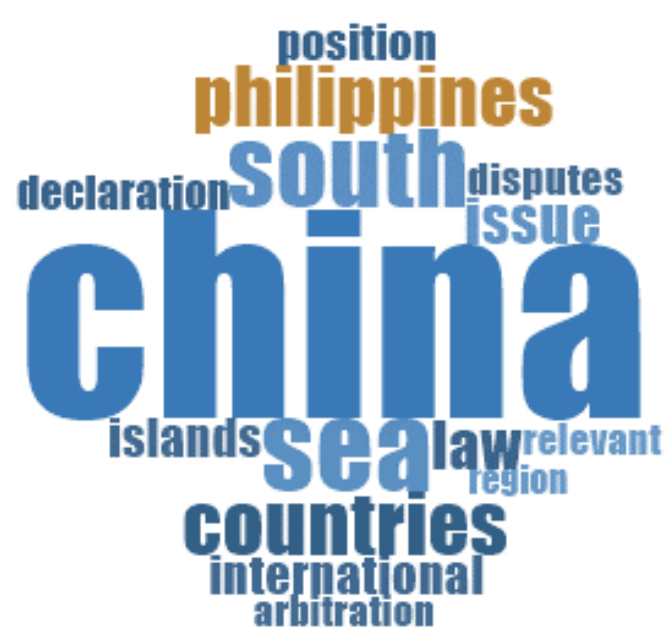

Figure 3. Words cloud of the transcript of regular press conference from 2014 to 2017

\section{$2017-2020$}

102 questions about the South China Sea were being asked in this period, 55 of them were America concerned. Among those US-related questions, only 6 were irrelevant to military operations and deployment. The question attached to military force was first brought up in 2016, and it was raised 3 times during the whole of 2016. After 2017, the word "militarization" was mentioned 23 times, "warship" related words appeared 86 times, "aircraft" related words 16 times. As it shows, military confrontation between China and the US is becoming more and more frequent in the South China Sea. Although the issue was barely brought up in the conference press in 2020, the frequency of naval exercises of both China of America hit a record high. On average, there were two exercises per month (Hong, 2020). At this stage, facing the military threat of the United States, China also began to use force to 
retaliate, the contradiction between China and the US has become the biggest factor affecting the situation in the South China Sea. Chinese policy has slowly changed after 2017, it claimed that China "Do not give up the possibility of a military solution" (Wu, 2020). According to the logic of moral realism, China is now a rising state with a proactive leader, the strategic preference is seeking to increase the international power of the country according to the growth of its national strength, and the expansion process is bound to extend from neighboring countries to the outside. While the dominant power America with the aggressive leadership tends to use violence to contain China, it means the risk of military conflict between China and the US on the periphery of China is very high. Now the new leadership type of America is remaining unknown, the future development of the situation in the South China Sea still needs further observation.

In Sum, the Chinese policy preference towards the South China Sea from 2009 to 2013 fits the hypothesis of moral realism that is preferred to avoid conflict with any countries, the emphasis of the policy was seeking cooperation for its economic interests. Moral realism also provides a good reason to upgrade the confrontation between China and the US, but it failed to explain why the friction between China and its neighbors was also intensified. Since 2017, the South China Sea is gradually becoming militarized, as moral realism predicts. The future of the South China Sea depends on the leadership type of the new president of the US.

\section{Conclusion \& Discussion}

Moral realism based on the assumption of realism and the methodology of behaviorism, it illustrates that political leadership serves as the core independent variable, leadership type is the core to change the international configuration. According to the attitude of status quo and strategic credibility, political leadership can be divided into inactive, conservative, proactive and aggressive. The strategic preference of a state is determined by the combination of its comprehensive strength and the leadership type, and the outcome of the international competition between a rising state and a dominant state depends on the preference of both sides. Following this logic, this paper defined the leadership type of America as conservative and aggressive, and the type of their Chinese counterpart as conservative and proactive. Theoretically, the strategic preference of the US should switch from controlling the hegemony cost, reduce military spending overseas to using all means including military one to contain the rising state, whilst Chinese policy preference should firstly be avoided conflict and seek for economic cooperation, then pursue political and military support from neighboring countries, when the latter preference of those sides come along, there will be a high risk of military confrontation between the two countries.

This paper analyzed questions related to the South China Sea raised at the regular press conference of the Ministry of Foreign Affairs of China, found that from 2009 to 2013 the total number is relatively low, from 2014 to 2016 experienced a rapid rise, the number of 2017 to 2020 period remains high. From 2009 to 2013, only two questions were about America, and the answers China gave were very neutral. It can be interpreted as China's policy on the South China Sea was to maintain the status quo. From 2014 to 2016, 30 out of 71 questions were related to the US, questions attached to military force brought up for the first time in this period. Noticeably, questions about frictions of neighboring countries also had a significant increase. 55 out of 102 of America's concerning questions were raised during 2017 to 2020 , only 6 of them were irrelevant to military operations and deployment. This can be seen as the South China Sea has slowly militarized.

Implied this logic of moral realism into the case of the South China Sea issue, it successfully explains the controllable period from 2009 to 2013, the escalation of tension between China and the US from 2014 to 2016, it also predicts the gradual militarization of South China Sea after 2017, and the future trend will depend on the leadership type of the new president of the US. But moral realism is the friction between China and its neighboring country when China should imply a good- neighborly policy. This might due to the fact that moral realism is a political determinism theory that absolutes the political factors, it ignores the influence of economy and culture in international relations. In the face of complex international issues, we should judge the determinants in light of the actual situation, because in some cases political factors play a more important role than economic and cultural factors, and sometimes economic and cultural factors might be decisive, but how to bring those two factors into moral realism is beyond this paper. Also, this paper only chose the Chinese Ministry of Foreign Affairs as the analysis object, American foreign policy is not mentioned. This is one of the limitations of this paper, more research needs to be done in this area. Although there is still a lot of room for moral realism to grow, it does provide a new lens through to view international relations.

\section{References}

Daidson, P. (2019). Speech at Reagan National Defense Forum. Ronald Reagan. Retrieved from https://www.reaganfoundation.org/reagan-institute/programs/reagan-national-defense-forum/

Demir, E. (2017). The Chinese School of International Relations: Myth or Reality? All Azimute, 95-104. 
Deng, X. (1983). Selected Works of Deng Xiaoping. Beijing: People's Publishing House.

Deng, Y. (2020). China's diplomacy can not go back to Keeping a Low Profile. Retrieved from https://p.dw.com/p/3a3QL

Diao, D. (2019). The logic, causes and effects of the Trump Administration's foreign policy. Modern International Relations, 19-27.

Fu, Y., \& Wu, S. (2016). The situation in the South China Sea and the dispute over Nansha Islands: historical review and realistic thinking. Retrieved from http://il.chineseembassy.org/chn/xzt/diyi111/t1364503.htm

Gordon, P. (2017). A Vision of Trump at War: How the President Could Stumble Into Conflict. Foreign Affairs, $10-37$.

Guerlain, P. (2014). Obama's Foreign Policy: “Smart Power," Realism and Cynicism. Society, 482-491.

Guo, S. (2017). The Growth of Chinese Consciousness and the Prospect of Chinese School in the Construction of China's IR theory. International Observation, 19-39.

Heydarian, R. J. (2020). US Ends Neutrality Position in South China Sea. China and US Focus. Retrieved from http://cn.chinausfocus.com/m/42007.html

Hong, S. (2020). The American and Chinese armies drill together at sea, who has the biggest muscle?. Retrieved from https://www.dw.com/zh/\%E7\%BE\%8E\%E4\%B8\%AD\%E4\%B8\%A4\%E5\%86\%9B\%E5\%90\%8C\%E6\%B 5\%B7\%E6\%93\%8D\%Е7\%BB\%83-\%Е8\%B0\%81\%E7\%9A\%84\%E8\%82\%8C\%E8\%82\%89\%E5\%A4\%A 7/a-54064952

Hu, J. (2005). Strive to build a harmonious world of lasting peace and common prosperity. Ren Min Ri Bao, 3-4.

$\mathrm{Hu}$, J. (2007). Hold the great banner of socialism with Chinese Characteristics and Strive for new victories in building a moderately prosperous society in all respects: Report delivered at the 17th National Congress of the CPC. Ren Min Ri Bao, 1-3.

Indyk, M., Lieberthal, K., \& O'Hanlon, M. (2012). Bending History: Barack Obama's Foreign Policy. Washington DC: Brookings Institution Press.

Jin, C., \& Jin, J. (2018). China's diplomacy in the 40 years of reform and opeaning-up. Pacific Study, 1-8.

Jisi, W. (2017). Trump's foreign policy and China-US relations. Contemporary American Review, 38-42.

Kim, H. (2016). Will IR Theory with Chinese Characteristics be a Powerful Alternative?. The Chinese Journal of International Politics, 59-79.

Kissinger, H. (2014). World Order. London: Penguin Books Limited.

Kristensen, P., \& Nielsen, R. (2013). Constructing a Chinese International Relations Theory: A Sociological Approach to Intellectual Innovation. International Political Sociology, 19-40.

Lida, M. (2020). Xi Jinping's diplomacy and the rise of his political authority. Journal of Contemporary East Asia Studies, 1-17.

Mearsheimer, J. (2013). Retrieved from https://www.guancha.cn/YanXueTong/2013_12_03_189543.shtml

Men, H. (2016). From Chinese Characteristics to Chinese School: Reflections on the Construction of Chinese International Political Theory. International Observation, 1-13.

Mettler, S. (2017). Democracy on the Brink: Protecting the Republic in Trump's America. Foreign Affairs, 119-134.

Ministry of Foreign Affairs of PRC. (2012). Retrieved from https://www.fmprc.gov.cn/web/fyrbt_673021/t1843828.shtml

Ministry of Foreign Affairs of PRC. (2014). Retrieved from https://www.fmprc.gov.cn/web/wjdt_674879/fyrbt_674889/t1816405.shtml

Morgenthau, H. (1948). Politics Among Nations: The Struggle for Power and Peace.

Nau, H. (2013). Conservative Internationalism: Armed Diplomacy under Jefferson, Polk, Truman, and Reagan. Princeton: Princeton Unicersity Press.

Nye, J. $\quad$ (2019). $\quad$ Retrieved from https://www.project-syndicate.org/commentary/trump-long-term-effect-on-american-foreign-policy-by-jose 
ph-s-nye-2019-09?barrier=accesspaylog

$\begin{array}{lll}\text { Obama, } & \text { B. } & \text { (2010). Retrieved from }\end{array}$ http://www.whitehouse.gov/the-press-office/remarks-president-gop-house-issues-conference

$\begin{array}{llll}\text { Obama, } & \text { B. } & \text { (2011). Retrieved from }\end{array}$ https://www.whitehouse.gov/the-press-office/2011/11/17/remarks-president-obama-australian-parliament

$\begin{array}{llll}\text { Obama, } & \text { B. } & \text { (2014). Retrieved from }\end{array}$ https://www.whitehouse.gov/the-press-office/2014/05/28/remarks-president-united-states-militaryacademycommencement-ceremony

Pan, Z., \& Chen, K. (2019). An Introduction to the Political Theory of Chinese Foreign Relations. World Economics and Politics, 20-38.

Russel, D. (2014). Retrieved from http://www.state.gov/p/eap/rls/rm/2014/02/221293.htm

Tao, W. (2016). Obama's diplomatic legacy. Peace and Development, 1-14.

The White House. $\quad$ (2017). Retrieved from https://www.whitehouse.gov/wp-content/uploads/2017/12/NSS-Final-12-18-2017-0905.pdf

Trigkas, V. (2020). On Global Power Differentials, Moral Realism, and the Rise of China: A Review Essay. Journal of Contemporary China, 950-963.

Wang, J. (2017). Trump's foreign policy and China-US relations. Contemporary American Review, 38-42.

Wang, J., \& Buzan, B. (2014). The English and Chinese Schools of International Relations: Comparisons and Lessons. The Chinese Journal of International Politics, 1-46.

$\mathrm{Wu}$, S. (2020). What will happen to the US in the South China Sea. Retrieved from http://www.nanhai.org.cn/review_c/450.html

$\mathrm{Xi}$, J. (2013). Speech in the Moscow State Institute of International Relations. Retrieved from http://www.xinhuanet.com//politics/2013-04/12/c_124574701.htm

$\mathrm{Xi}$, J. (2016). The Political Bureau of the 18th CPC Central Committee studied together. Retrieved from Political Bureau of the CPC Central Committee: http://politics.people.com.cn/GB/8198/385219/

Xi, J. (2016). Xi met with President of the European Council Donald Tusk and President of the European Commission Jean-Claude Juncker. The Xinhua News Agency. Retrieved from http://xuexi.cctv.com/2016/07/12/ARTI254jCNb0GM340hPQL4dC160712.shtml

$\mathrm{Xi}$, J. (2017). Building a moderately prosperous society in all respects and achieve the great victory of socialism with Chinese characteristics for a new era. Retrieved from http://www.gov.cn/zhuanti/2017-10/27/content_5234876.htm

Xi, J. (2017). Xi Jinping meets with former US President Barack Obama. The Xinhua News Agency. Retrieved from http://www.xinhuanet.com//politics/leaders/2017-11/30/c_1122038612.htm

Xi, J. (2018). China's diplomacy must be fit Its Major-Power Status. The Governance of China, 483.

Yan, X. (2014). From Keeping a Low Profile to Striving for Achievement. The Chinese Journal of International Politics, 153-184.

Yan, X. (2016). Political Leadership and Power Redistribution. The Chinese Journal of International Politics, $1-26$.

Yan, X. (2019). Leadership and the Rise of Great Powers. Princeton: Prineton Unicersity Press.

Yan, X., \& Yang, Y. (2013). The Analysis of International Relations. Beijing: Beijing University Press.

Yang, X. (2016). Political Leadership and Power Redistribution. The Chinese Journal of International Politics, $1-26$.

Zhang, J. (2020). When will the "Wolf Warrior Diplomacy" cease? Retrieved from https://www.dw.com/zh/\%E5\%AE\%A2\%E5\%BA\%A7\%E8\%AF\%84\%E8\%AE\%BA\%E4\%B9\%A0\%Е6\% B0\%8F\%E6\%88\%98\%E7\%8B\%BC\%E5\%A4\%96\%E4\%BA\%A4\%E4\%BD\%95\%E6\%97\%B6\%E4\%BC $\% 91 / \mathrm{a}-54508194$

Zhang, Q. (2014). Understand China's diplomacy since the 18th CPC National Congress. Foreign Affairs Review, 1-20. 
Zhang, Q., \& Yang, L. (2017). China's Diplomatic Transformation and Institutional Innovation. Chinese Diplomacy Review, 22-53.

Zhou, F. (2019). Alliance Management uncer limited strategic contraction: Strategic options for the Obama and Trump Administrations. Quarterly Journal of International Politics, 1-34.

Zhu, F. (2018). The Trump administration's policy on the South China Sea and the challenges of maritime security between China and the US. Contemporary America Review, 1-22.

\section{Copyrights}

Copyright for this article is retained by the author(s), with first publication rights granted to the journal.

This is an open-access article distributed under the terms and conditions of the Creative Commons Attribution license (http://creativecommons.org/licenses/by/4.0/). 